\title{
Physiological potential and fungi control of Moringa oleifera Lamark seeds treated with essential oils
}

\author{
Potencial fisiológico e controle de fungos de sementes de Moringa oleifera Lamark tratadas \\ com óleos essenciais
}

\author{
M. L. S. Medeiros*; H. I. Jesus; O. R. Farias; J. M. F. L. Cruz; L. C. Nascimento \\ Postgraduate Program in Agronomy, Universidade Federal da Paraíba, 58397-000, Areia-Paraíba, \\ Brazil
}

*luizamedeiros30@hotmail.com

(Recebido em 27 de abril de 2020; aceito em 30 de julho de 2020)

\begin{abstract}
Moringa oleifera Lam. is a fast-growing, drought-resistant, rustic plant with high nutritive value. The aim of the present study was to determine the effectiveness of essential oils from citronella grass (Cymbopogon winterianus), lemongrass (Cymbopogon citratus) and thyme (Thymus vulgaris) on the reduction of the incidence of fungi associated with moringa seeds as well as the influence of these oils on the physiological quality of the seeds. Two experiments were conducted, both with an entirely randomized design. The seeds were treated with the citronella, lemongrass and thyme essential oils at concentrations of 250 and $500 \mu \mathrm{L}$ (100 seeds per treatment). The fungicide Captan was used as the control treatment. The incidence of fungi on the treated seeds was evaluated in the first experiment. The germination percentage, shoot length, primary root length, shoot dry mass and root dry mass of the seedlings were evaluated in the second experiment. The most incident fungus was also isolated for the transmission test. The following fungi were identified on the moringa seeds: Fusarium spp., Nigrospora sp., Aspergillus sp., Penicillium sp., Alternaria sp., Phomopsis sp., Curvularia sp., Colletotrichum sp., Pestalotipsis sp., Lasiodiplodia sp. and Chaetomium sp. The essential oils significantly reduced the incidence of the fungi. However, changes in the physiological quality of the seeds were associated with the use of the oils. No transmission of Fusarium spp. from the seeds to the seedlings occurred, but this fungus caused the rotting of seeds in the germination phase.
\end{abstract}

Keywords: moringa, vigor, incidência de fungos.

Moringa oleifera Lam. é uma planta rústica de crescimento rápido, resistente à seca e com alto valor nutritivo. O objetivo do presente estudo foi determinar a eficiência de óleos essenciais de capim-citronela (Cymbopogon winterianus), capim-limão (Cymbopogon citratus) e tomilho (Thymus vulgaris) na redução da incidência de fungos associados às sementes de moringa, bem como a influência desses óleos na qualidade fisiológica das sementes. Foram realizados dois experimentos, ambos com delineamento inteiramente casualizado. As sementes foram tratadas com os óleos essenciais de citronela, capim-limão e tomilho nas concentrações de 250 e $500 \mu \mathrm{L}$ (100 sementes por tratamento). $\mathrm{O}$ fungicida Captan foi utilizado como tratamento controle. A incidência de fungos nas sementes tratadas foi avaliada no primeiro experimento. A porcentagem de germinação, comprimento da parte aérea, comprimento da raiz primária, massa seca da parte aérea e massa seca da raiz das plântulas foi avaliada no segundo experimento. $\mathrm{O}$ fungo mais incidente também foi isolado para o teste de transmissão. Os seguintes fungos foram identificados nas sementes de moringa: Fusarium spp., Nigrospora sp., Aspergillus sp., Penicillium sp., Alternaria sp., Phomopsis sp., Curvularia sp., Colletotrichum sp., Pestalotipsis sp., Lasiodiplodia sp. e Chaetomium sp. Os óleos essenciais reduziram significativamente a incidência dos fungos. Entretanto, alterações na qualidade fisiológica das sementes foram associadas ao uso dos óleos. Nenhuma transmissão de Fusarium spp. das sementes às plântulas foi constatada, mas esse fungo causou o apodrecimento das sementes na fase de germinação.

Palavras-chave: moringa, vigor, fungi incidence.

\section{INTRODUCTION}

Moringa oleifera Lamark. belongs to the family Moringaceae, is native to India and grown in tropical regions throughout the world [1]. The average height of the plant is about $5 \mathrm{~m}$; however, under favourable condition it reaches up to $10 \mathrm{~m} \mathrm{[2].} \mathrm{Moringa} \mathrm{oleifera} \mathrm{trees} \mathrm{are} \mathrm{characterized} \mathrm{by}$ its divided leaves, thin crown, whitish flowers, fruit capsule and winged type with a dehiscent aspect of a pod having markings for measuring seed up to $35 \mathrm{~cm}$ [3]. This fast-growing rustic 
plant have low water requirements, which is a very relevant feature for a region with sparse rains events, in which plants are under severe environmental stresses. Thus, the cultivation of moringa has been suggested as a viable alternative for the semiarid region of northeastern Brazil.

In addition to its use as an ornamental tree, the specie is known for its great versatility [4]. The leaves are supplied to animals as forage while the seeds are used for medicinal and industrial purposes. The wood is used to produce paper and textile fibers. The roots are considered abortive [5] and have been widely used by the pharmaceutical industry to combat in deficiency of vitamins $\mathrm{A}$ and $\mathrm{C}$, in rheumatism and gout treatments, such as wound healing. In addition, the plant is known to have several pharmacological benefits for human consumption including growth promotion, antimicrobial, therapeutic and antioxidant effects [6].

The interest in the production of forest seedlings has increased in recent years due to the use of these plants for recovering degraded areas and the re-composition of the landscape [7]. The establishment of moringa can be done through direct sowing, planting with cuttings and transplanting seedlings produced in nurseries. Studies carried out with this species have shown that sowing in the final field is advantageous, since the moringa seedlings are fragile and losses are registered during transplantation [8]. Thus, this species can be cultivated by planting seeds that germinate easily. The plant produces many seeds and this production starts after six months to one year after planting [9].

For the successful production of seedlings and plant establishment, it is essential to use high quality seeds, expressed by genetic, physical and physiological attributes that are responsible for originating plants with high vigour [10]. One of the factors that can affect the quality of the seedlings is the difficulty of obtaining pathogen-free seeds, once those are one of the main sources of the dissemination and transmission of several pathogens associated with diseases that directly impact plant establishment $[11,12]$.

Seed-associated pathogens can cause different forms of harm, such as the loss of germinative power and a reduction in the vigour of the seedlings, including the possibility of pre-emergence and post-emergence death, root rot and infection of the sprout [11]. Studies carried out with Moringa oleifera found several fungal species to be seed transmitted, such as Aspergillus niger, Aspergillus flavus, Alternaria sp, Fusarium sp, Penicillium sp and Phomopis sp. [13, 14].

The treatment of seeds is generally performed with synthetic fungicides. Despite the importance of these products, their continual and inadequate use causes harm to the environment as well as both human and animal health and the high cost of these substances leads to a considerable increase in production costs $[11,15]$. The use of alternative methods from natural sources, such as essential oils, constitutes a sustainable replacement for chemical products in the management of pathogens on seeds [16].

Studies have demonstrated the effectiveness of different essential oils for the control of seedassociated pathogens, such as the oil from the andiroba (Carapa guianensis Aubl) and diesel tree (Copaifera langsdorffii Desf.) on cowpeas (Vigna unguiculata L. Walp) [14], clove oil (Syzygium aromaticum (L.) Merr. \& L. M. Perry) and diesel tree oil (Copaifera langsdorffii Desf) on "fava d'anta" seeds (Dimorphandra gardneriana Tuslane) [11], and clove oil (Syzygium aromaticum L.) and diesel tree oil (Copaifera langsdorffii) on the "Sodom apple" tree seeds (Calotropis procera Ait. R. Br.) [17].

Despite the effectiveness in controlling seed-associated pathogens, these essential oils can also exert a negative impact on germinative power and plant vigour [14]. However, oils can also preserve the physiological quality of the treated seeds [11]. Therefore, the aim of the present study was to determine the effectiveness of different concentrations of the essential oils from citronella grass (Cymbopogon winterianus Jowitt ex Bor), lemongrass (Cymbopogon citratus (DC.) Stapf) and thyme (Thymus vulgaris L.) regarding the reduction in the incidence of fungi associated with Moringa oleifera Lam. seeds as well as the effect of these oils on physiological quality of the seeds and seedlings. 


\section{MATERIAL AND METHODS}

\subsection{Experiment location}

The experiment was conducted at the Phytopathology Laboratory of the Center for Agrarian Sciences of the Universidade Federal da Paraíba (UFPB), Campus II, Areia, PB, Brazil.

\subsection{Collection and sorting of moringa seeds}

Moringa seeds (Moringa oleifera Lam.) were collected from a matrix located in Parque dos Coqueiros in the city of Natal, RN, Brazil. The seeds were sorted manually. Those with malformations or attacked by pests were discarded and the rest were stored in a cold chamber at $15 \pm 2^{\circ} \mathrm{C}$ for 30 days.

\subsection{Control of fungi associated with moringa seeds treated with essential oils}

The seeds (100 per treatment) were treated with three essential oils obtained commercially by immersion in the different solutions for five minutes. The treatments were composed as follows: T1 - Negative control (seeds disinfected with $1 \%$ sodium hypochlorite for three minutes); T2 citronella oil at $250 \mu \mathrm{L}$; T3 - citronella oil at $500 \mu \mathrm{L}$; T4 - lemongrass oil at $250 \mu \mathrm{L}$; T5 lemongrass oil at $500 \mu \mathrm{L}$; T6 - thyme oil at $250 \mu \mathrm{L}$; T7 - thyme oil at $500 \mu \mathrm{L}$; T8 - Captan fungicide $(240 \mathrm{~g} / 100 \mathrm{~kg}$ of seeds).

In the detection of microorganisms, the paper substrate incubation method ("blotter test") was used [18], which consists of fungal growth on seeds submitted to a humid environment. For the method, Petri dishes $(\varnothing 15 \mathrm{~cm})$ previously disinfected with a double layer filter paper that was previously sterilized and moistened with $10 \mathrm{~mL}$ of sterile distilled water (SDW) were used. The seeds were divided into 10 replications of 10 units, which were individually distributed on Petri dishes, following aseptic conditions. The dishes were incubated at $25 \pm 2^{\circ} \mathrm{C}$ for seven days. After this period, quantification and identification of fungi were performed, in gender level, based on its morphological characteristics visualized with the aid of stereoscopic, optical microscopes and specialized literature [19], the seeds being observed individually. The results were expressed as percentage of the incidence of fungi per seed.

\subsection{Physiological quality of moringa seeds treated with essential oils}

The following tests were performed to evaluate the influence of the citronella, lemongrass and thyme oils on the physiological quality of the moringa seeds:

Germination test: 100 seeds were distributed into four repetitions of 25 seeds each and placed in "germitest" paper rolls moistened to 2.5 times the dry weight of the paper. The rolls were placed in transparent plastic bags to avoid the loss of water and then and placed into biochemical oxygen demand (BOD) chamber set at $25^{\circ} \mathrm{C}$ with an eight-hour photoperiod. Counts of normal seedlings were performed on the $4^{\text {th }}$ and $10^{\text {th }}$ day after sowing [18].

First germination count: conducted concomitantly to the germination test; germinated seeds were counted on the $4^{\text {th }}$ day after sowing [18].

Germination rate index (GRI): The number of germinated seeds was recorded daily from the $4^{\text {th }}$ to $10^{\text {th }}$ day. The GRI was determined based on the equation proposed by Maguire [20].

Length and dry mass of seedlings: The length of 100 seedlings into four repetitions of 25 seedlings was assessed in both tests individually. With a digital caliper ( $0.001 \mathrm{~mm}$ accuracy), the length of the shoot and root of the seedlings was gauged, and the results were delivered in centimeters. Subsequently, shoots and roots were separately packed in Kraft paper bags, and then taken to a forced air convection oven set at $65^{\circ} \mathrm{C}$ for $48 \mathrm{~h}$. After that time, having the samples reached a constant weight, the dry mass of each seedling part was weighed in an analytical balance (0.001 $\mathrm{g}$ accuracy) and the results were expressed in grams [21]. 


\subsection{Transmission of Fusarium spp. from moringa seeds to seedlings}

After the identification of the fungi, the species having the highest incidence on the moringa seeds (Fusarium spp.) was isolated from infected seeds for the subsequent transmission test, following the methodology of Sousa et al. (2008) [22]. To isolate Fusarium spp., fragments of the mycelia growing on the seeds were transferred to a potato-dextrose-agar (PDA) medium and incubated in Petri dishes at $25 \pm 2^{\circ} \mathrm{C}$ for seven days in BOD. After confirmation of Fusarium sp., the fungus was multiplied in another medium containing PDA at $25 \pm 2{ }^{\circ} \mathrm{C}$ for the transmission test.

For the transmission test, 100 seeds were disinfected with a $1 \%$ solution of sodium hypochlorite for three minutes [10], followed by three successive rinses with sterilized distilled water (ADE) and placed in plastic trays within sterilized filter paper to remove the excess moisture.

Inoculation with Fusarium spp. was performed by direct contact of the seeds with the fungal colony on Petri dishes with exposure for 24 hours [22]. The seeds were then sown at a depth of 2 $\mathrm{cm}$ into plastic trays containing a commercial substrate that had previously been autoclaved twice ( $1 \mathrm{~atm}, 120^{\circ} \mathrm{C}$ for $60 \mathrm{~min}$, with a 24 -hour interval between autoclaving sessions). The trays were kept in a greenhouse for 20 days with the temperature ranging from 28 to $30^{\circ} \mathrm{C}$ during the day and 18 to $20^{\circ} \mathrm{C}$ at night. Irrigation was performed manually once a day. During the period of emergence and at the final evaluation, the seedlings with pre-emergence and post-emergence symptoms of infection were counted, removed and placed in a humidity chamber for the isolation of the pathogen and confirmation of the causal agent.

\subsection{Statistical Analysis}

The treatments were arranged in a completely randomized design with four replications. The normality of sample means was determined by the Shapiro-Wilk test. The fungal infection data were transformed into $\sqrt{y}+0.5$. The infection and physiological quality data were compared using Tukey's test with a $5 \%$ probability level. The Sisvar ${ }^{\circledR}$ software was used for the statistical analysis [23].

\section{RESULTS}

Table 1 shows the results of analyses of variance for first germination count (FGC), germination $(G)$, germination velocity index (GRI), shoot length (SL), root length (RL), shoot dry matter (SDM), root dry matter (RDM) and for the fungal species Fusarium spp. (FUS), Nigrospora sp. (NIG), Aspergillus sp. (ASP), Penicillium sp. (PEN), Alternaria sp. (ALT), Phomopsis sp. (PHO), Curvularia sp. (CUR), Colletotrichum sp. (COL), Pestalotipsis sp. (PES), Lasiodiplodia sp. (LAS) and Chaetomium sp. (CHA). The analyses of variance showed statistically significant effects of treatments for all traits evaluated, except for the fungal species Curvularia sp., Colletotrichum sp., Pestalotipsis sp., Lasiodiplodia sp. and Chaetomium sp.

Table 1. Analysis of variance (ANOVA) mean squares for each source of variation.

\begin{tabular}{|c|c|c|c|c|c|c|c|}
\hline \multirow[t]{2}{*}{$\begin{array}{l}\text { Source of } \\
\text { Variation }\end{array}$} & \multirow[t]{2}{*}{ DL } & \multicolumn{6}{|c|}{ Mean Squares } \\
\hline & & FGC & G & GRI & SL & RL & SDM \\
\hline Treatment & 7 & $55.13 * *$ & $997.71 * *$ & $135.76^{* *}$ & $2.77 * *$ & $6.71 * *$ & $1 \mathrm{E}-03 * *$ \\
\hline \multirow[t]{2}{*}{ Error } & \multirow[t]{2}{*}{24} & 1.29 & 46.00 & 6.48 & 0.72 & 2.04 & 1E-04 \\
\hline & & RDM & FUS & NIG & ASP & PEN & ALT \\
\hline Treatment & 7 & $2 \mathrm{E}-04 * *$ & $1.34 * *$ & $0.59 * *$ & $0.28 * *$ & $0.13 * *$ & $0.05 *$ \\
\hline \multirow[t]{2}{*}{ Error } & \multirow[t]{2}{*}{24} & $6 \mathrm{E}-05$ & 0.09 & 0.03 & 0.20 & 0.02 & 0.02 \\
\hline & & $\mathrm{PHO}$ & CUR & $\mathrm{COL}$ & PES & LAS & $\mathrm{CHA}$ \\
\hline Treatment & 7 & $0.04 * *$ & $0.04^{\mathrm{NS}}$ & $0.01^{\mathrm{NS}}$ & $0.01^{\mathrm{NS}}$ & $0.01^{\mathrm{NS}}$ & $0.01^{\mathrm{NS}}$ \\
\hline Error & 24 & 0.01 & 0.03 & 0.01 & 0.01 & 0.01 & 0.01 \\
\hline
\end{tabular}

**, *, NS - Significant at $0.01,0.05$ probability levels and not significant by the F test, respectively. 
The respective fungi and incidence rates on the moringa seeds (Negative control) were Fusarium spp. (31.0\%), Nigrospora sp. (17.0\%), Aspergillus sp. (10.0\%), Penicillium sp. (7.0\%), Alternaria sp. (4.0\%), Phomopsis sp. (4.0\%), Curvularia sp. (2.0\%), Colletotrichum sp. (2.0\%), Pestalotipsis sp. (2.0\%), Lasiodiplodia sp. (1.0\%) and Chaetomium sp. (1.0\%) (Figure 1).

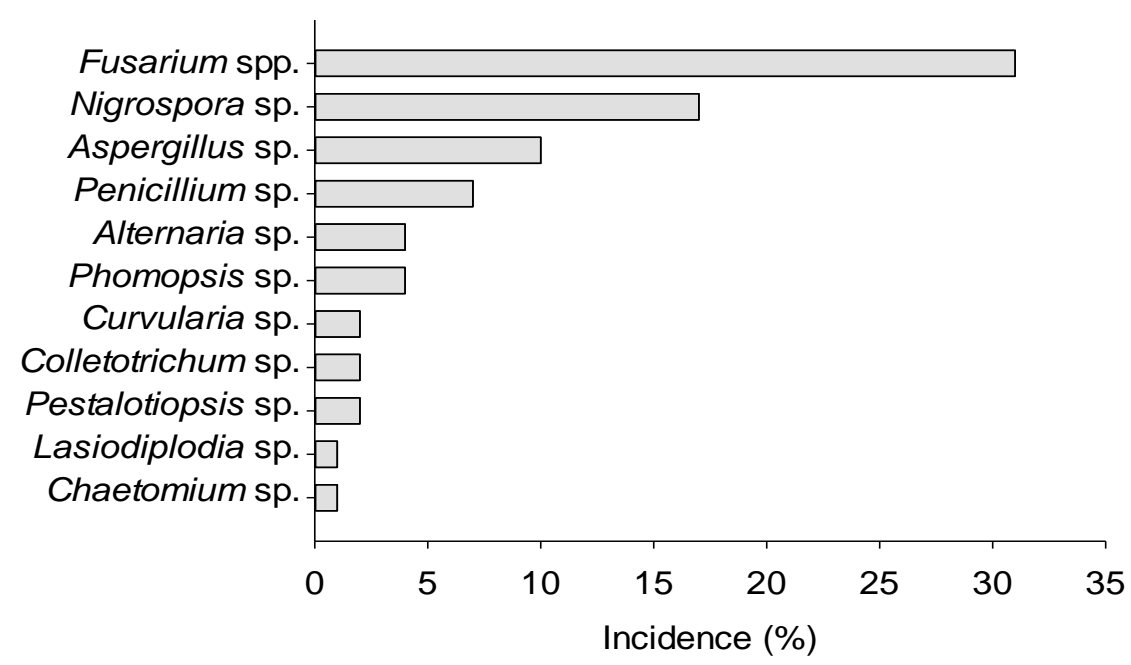

Figure 1. Incidence of fungi on moringa (Moringa oleifera Lam.) seeds.

Among the fungi, Fusarium spp., Nigrospora sp., Aspergillus sp., Penicillium sp., Alternaria sp. and Phomopsis sp. had the statistically relevant incidences to enable comparisons between treatments (Figure 2). 

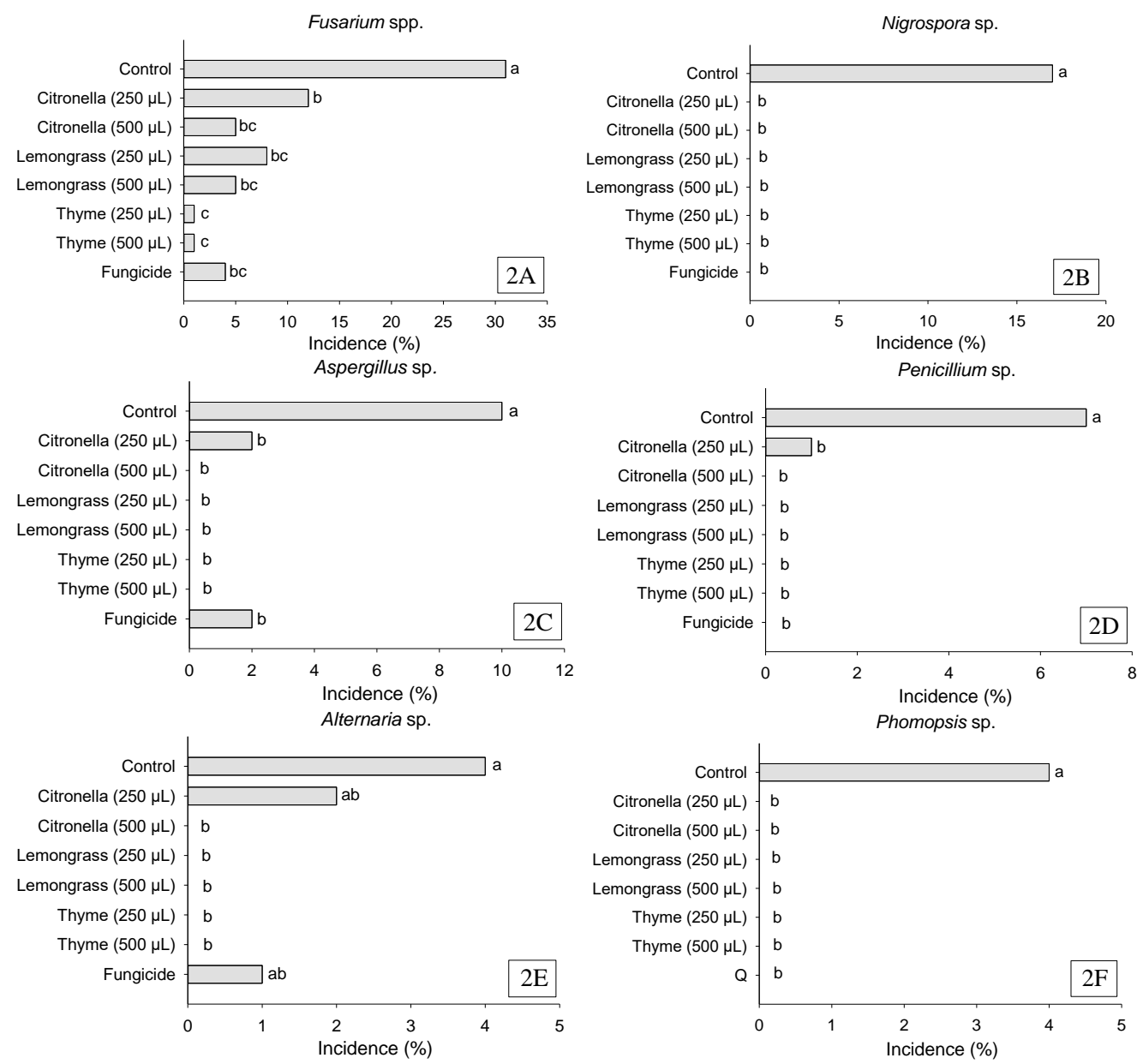

Figure 2. Incidence (\%) of Fusarium spp. (A), Nigrospora sp. (B), Aspergillus sp. (C), Penicillium sp.

$(D)$, Alternaria sp. $(E)$ and Phomopsis sp. $(F)$ on moringa (Moringa oleifera Lam.) seeds treated with essential oils of citronella, lemongrass and thyme in different concentrations.

All treatments led to a significant reduction in Fusarium spp. in comparison to the negative control (Figure 2A). A 96.9\% reduction in the incidence of this fungus was found when the thyme oil was used, independently of the concentration. These results did not differ significantly from those achieved with the commercial fungicide, lemongrass oil at 250 and $500 \mu \mathrm{L}$ and citronella oil at $500 \mu \mathrm{L}$, which led to reductions of $87.0 \%, 74.1 \%, 83.8 \%$ and $83.8 \%$, respectively. The citronella oil at $250 \mu \mathrm{L}$ led to a $61.29 \%$ reduction in the incidence of Fusarium spp. compared to the negative control (Figure 2A). The inhibitory effect demonstrates the fungitoxic potential of the essential oils, suggesting that these oils are potential substitutes for commercial fungicides in the control of these pathogens.

A $100 \%$ reduction in the incidence of Nigrospora sp., Aspergillus sp., Penicillium sp., Alternaria sp. and Phomopsis sp. was found with the essential oils (Figures 2B, 2C, 2D, 2E, 2F). The only exception was the citronella oil at a concentration of $250 \mu \mathrm{L}$.

Despite the effectiveness at inhibiting or reducing the growth of the pathogens identified on the moringa seeds, the citronella, lemongrass and thyme essential oils had a phytotoxic effect on the first germination count and GRI, with statistically significant differences in comparison to the negative control. The citronella oil at $250 \mu \mathrm{L}$, lemongrass oil at $250 \mu \mathrm{L}$ and thyme oil at $500 \mu \mathrm{L}$ had the greatest effect on the seeds in terms of the first germination count and GRI. The effect of these oils did not differ significantly from the commercial fungicide with the exception of the germination using thyme oil at $500 \mu \mathrm{L}$ (Table 2). 
Table 2. First germination count $(F G C)$, germination $(G)$, and germination rate index (GRI) of moringa (Moringa oleifera Lam.) seeds treated with essential oils of citronella, lemongrass and thyme in different

\begin{tabular}{llll}
\multicolumn{4}{c}{ concentrations. } \\
\hline Treatments & FGC $(\boldsymbol{\%})$ & G $(\%)$ & GRI \\
Negative control & $11.0 \mathrm{a}$ & $55.0 \mathrm{a}$ & $19.5 \mathrm{a}$ \\
Citronella $(\mathbf{2 5 0} \boldsymbol{\mu} \mathbf{L})$ & $0.5 \mathrm{c}$ & $22.0 \mathrm{c}$ & $1.7 \mathrm{c}$ \\
Citronella $(\mathbf{5 0 0} \boldsymbol{\mu} \mathbf{L})$ & $3.7 \mathrm{~b}$ & $50.0 \mathrm{ab}$ & $8.1 \mathrm{~b}$ \\
Lemongrass $(\mathbf{2 5 0} \boldsymbol{\mu} \mathbf{L})$ & $0.7 \mathrm{c}$ & $42.0 \mathrm{abc}$ & $6.9 \mathrm{bc}$ \\
Lemongrass $(\mathbf{5 0 0} \boldsymbol{\mu} \mathbf{L})$ & $1.2 \mathrm{bc}$ & $31.0 \mathrm{abc}$ & $3.9 \mathrm{~b}$ \\
Thyme $(\mathbf{2 5 0} \boldsymbol{\mu} \mathbf{L})$ & $1.7 \mathrm{bc}$ & $35.0 \mathrm{abc}$ & $4.6 \mathrm{bc}$ \\
Thyme $(\mathbf{5 0 0} \boldsymbol{\mu} \mathbf{L})$ & $0.5 \mathrm{c}$ & $6.0 \mathrm{~d}$ & $1.1 \mathrm{c}$ \\
Fungicide & $1.5 \mathrm{bc}$ & $27.0 \mathrm{bc}$ & $5.3 \mathrm{bc}$ \\
\hline CV $(\%)$ & 24.67 & 14.52 & 21.18 \\
\hline
\end{tabular}

Means with same letter in column do not differ significantly from each other at $5 \%$ probability level (Tukey's test).

In the germination test (Table 2), only 55\% of the untreated seeds germinated, not achieving the minimum germination rate required for the commercial production of basic seeds, which is $65 \%$ [24]. The citronella oil at $500 \mu \mathrm{L}$, lemongrass oil at 250 and $500 \mu \mathrm{L}$ and thyme oil at 250 $\mu \mathrm{L}$ had germination rates similar to the negative control, with no statistically significant differences, suggesting that the adjustment of the concentrations of these oils could generate more satisfactory results in the treatment of the seeds.

Regarding the shoot and root length of the seedlings, no significant differences were found between the negative control and the oils, however there was a difference between the oils and the concentrations tested. The lowest values for these variables were found for the lemongrass oil at $500 \mu \mathrm{L}$ and thyme oil at $500 \mu \mathrm{L}$, respectively, with significant differences only from citronella oil at $500 \mu \mathrm{L}$ (Table 3).

Table 3. Shoot length (SL), root length (RL), shoot dry matter (SDM) and root dry matter (RDM) of moringa (Moringa oleifera Lam.) seedlings treated with essential oils of citronella, lemongrass and thyme in different concentrations.

\begin{tabular}{lllll}
\hline Treatments & SL $(\mathbf{c m})$ & RL $(\mathbf{c m})$ & SDM $(\mathbf{g})$ & RDM $(\mathbf{g})$ \\
\hline Negative control & $3.0 \mathrm{ab}$ & $1.75 \mathrm{ab}$ & $0.040 \mathrm{ab}$ & $0.020 \mathrm{ab}$ \\
Citronella $(\mathbf{2 5 0} \boldsymbol{\mu L})$ & $1.3 \mathrm{ab}$ & $2.25 \mathrm{ab}$ & $0.013 \mathrm{c}$ & $0.017 \mathrm{ab}$ \\
Citronella $(\mathbf{5 0 0} \boldsymbol{\mu L})$ & $3.2 \mathrm{a}$ & $5.4 \mathrm{a}$ & $0.053 \mathrm{a}$ & $0.032 \mathrm{a}$ \\
Lemongrass $(\mathbf{2 5 0} \boldsymbol{\mu} \mathbf{L})$ & $1.9 \mathrm{ab}$ & $2.5 \mathrm{ab}$ & $0.026 \mathrm{bc}$ & $0.024 \mathrm{ab}$ \\
Lemongrass $(\mathbf{5 0 0} \boldsymbol{\mu} \mathbf{L})$ & $1.0 \mathrm{~b}$ & $1.5 \mathrm{~b}$ & $0.013 \mathrm{c}$ & $0.021 \mathrm{ab}$ \\
Thyme $(\mathbf{2 5 0} \boldsymbol{\mu} \mathbf{L})$ & $1.6 \mathrm{ab}$ & $2.2 \mathrm{ab}$ & $0.014 \mathrm{c}$ & $0.020 \mathrm{ab}$ \\
Thyme $(\mathbf{5 0 0} \boldsymbol{\mu L})$ & $1.1 \mathrm{~b}$ & $1.4 \mathrm{~b}$ & $0.008 \mathrm{c}$ & $0.007 \mathrm{~b}$ \\
Fungicide & $1.9 \mathrm{ab}$ & $1.9 \mathrm{ab}$ & $0.018 \mathrm{c}$ & $0.021 \mathrm{ab}$ \\
\hline CV $(\%)$ & 21.11 & 24.68 & 20.80 & 20.51 \\
\hline
\end{tabular}

Means with same letter in column do not differ significantly from each other at $5 \%$ probability level (Tukey's test).

The citronella oil at $500 \mu \mathrm{L}$ showed a higher accumulation of dry matter in the shoot and root, with a significant difference between all treatments, with the exception of the negative control in the shoot dry matter and only between the thyme oil at $500 \mu \mathrm{L}$ in the root dry matter (Table 3 ).

No transmission of Fusarium spp. from the seeds to the seedlings occurred. However, this fungus caused the rotting of seeds (57\%) in the germination phase (Figure 3). These results confirmed the results of the germination test, demonstrating that the lot of seeds had low germinative power. 


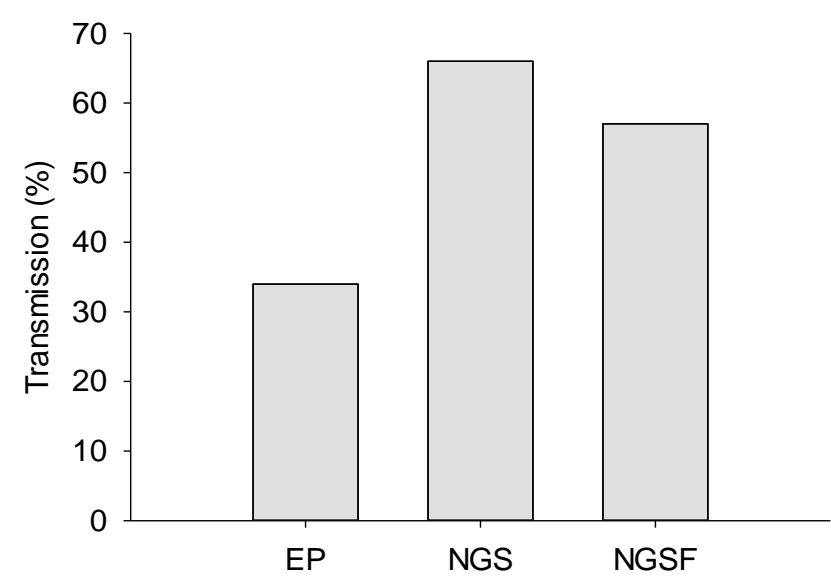

Figure 3. Percentage of emerged plants (EP), non-germinated seeds (NGS) and non-germinated seeds with Fusarium sp. (NGSF) for moringa (Moringa oleifera Lam.) seeds in transmission test.

\section{DISCUSSION}

Fusarium spp. was the fungus with the greatest incidence on the moringa seeds. This genus is responsible for the reduction of the germinative capacity of seeds, root rot and consequent death of infected seedlings [25]. Among the fungi identified on the seeds, Nigrospora sp. [26], Aspergillus sp. and Penicillium sp.) [27] are frequently found on seeds, causing deterioration and reducing the germinative potential and vigor of seedlings.

Several species of the genera Alternaria [28], Colletotrichum [29], Curvularia Silva et al. [30] and Pestalotiopsis [31] are reported causing leaf disease on different crops, including forest species. Phomopsis sp. is responsible for causing rot in seeds and infecting seedlings, significantly compromising the initial phase of the development and establishment of plants [32].

Fusarium spp. and Alternaria spp. are "field" fungi and Aspergillus spp. and Penicillium spp. are "storage" fungi that produce mycotoxins that cause harm to plants, animals and humans [27].

Chaetomium sp. occurred with a low frequency on the moringa seeds. Several studies report the considerable potential of this genus for use in biological control, since it is efficient at colonizing soil and substrates, playing a role in the control of various pathogens [33].

According to Costa et al. (2011) [34], the antifungal activity of essential oils is related to their hydrophobicity, which enables the interaction between the oil and lipids of the cell wall, membrane and mitochondria of the pathogen, leading to a change in permeability and causing damage to these structures. The thyme oil contains the phenols thymol and carvacrol [35], whereas the major component of the citronella and lemongrass oils is citral [36], all of which have effective fungicidal activity.

On the other hand, the results of the germination test, first germination index and GRI reveal a phytotoxic effect of the essential oils on the moringa seeds (Table 2). This effect has previously been observed on seeds of Vigna unguiculata treated with citronella oil Xavier et al. (2012) [37]. Analyzing the effect of essential oils on the control of pathogens and the germination of corn seeds, Jardinetti et al. (2011) [38] found that the thyme oil reduced the GRI when compared to the negative control. According to Reigosa et al. (1999) [39], the allelochemical effects on different physiological processes of a plant are dependent on the concentration. Thus, the fact that the treatments affected this index may be related to the high concentration of the oil and further studies are needed to test the effects of lower concentrations.

Studying the effects of essential oils from cinnamon (Cinnamomum zeylanicum Blume syn. C. verum J. Presl), pepper-rosmarin (Lippia sidoides Cham.), citronella (Cymbopogon citratus), clove basil (Ocimum gratissimum L.) and jaborandi (Pilocarpus microphyllus Stapf ex Wardleworth) on lettuce leaves, Alves et al. (2004) [40] found a concentration-dependent allelopathic effect (reducing or inhibiting plantlet growth) for the majority of the oils studied, with the exception of the jaborandi oil, which stimulated plant growth. 
The results of the transmission test underscore the evidence that the considerable incidence of pathogens may have compromised the physiological quality of the seeds, which would explain the low germinative power. Several studies have reported that, besides problems in the field, the genus Fusarium is also responsible for the rotting of seeds [41]. Silva et al. (2017) [42] also found no transmission of Fusarium spp. from the seeds to the seedlings of Pinus taeda, but this microorganism caused the rotting of seeds in the germination phase.

In this study, no lesions were found on the seedlings in the post-emergence period. However, several studies have reported the transmission of Fusarium spp. from seeds to seedlings. Using the transmission test, Walker et al. (2016) [25] found that Fusarium acuminatum and Fusarium verticillioides were pathogenic to Cordia americana L. Gottshling \& J.E.Mill. and Maciel et al. (2012) [43] found that Fusarium sp. was pathogenic to Parapiptadenia rigida Benth. Brenan. moreover, Lazarotto et al. (2012) [44] found that Fusarium spp. isolated from Cedrela fissilis Vell. Meliaceae. seeds were pathogenic to the seedlings, causing root damage and subsequent lack of vigor of the seedlings.

\section{CONCLUSION}

All treatments achieved control of up to $100 \%$ of the pathogens found on the moringa seeds, except the genus Fusarium spp. However, a 96.9\% reduction in the incidence of this microorganism was achieved with the thyme oil at concentrations of 250 and $500 \mu \mathrm{L}$.

The essential oils at the concentrations tested exerted a negative influence on the physiological quality of the moringa seeds.

\section{REFERENCES}

1. Karadi RV, Gadge NB, Alagawadi KR, Savadi RV. Effect of Moringa oleifera Lam. root-wood on ethylene glycol induced urolithiasis in rats. J Ethnopharmacol. 2006 Apr;105(1):306-311, doi: 10.1016/j.jep.2005.11.004

2. Zhao S, Zhang D. Supercritical fluid extraction and characterisation of essential oil from Moringa oleifera leaves. Separat Purific Technol. 2013 Oct;118(1):497-502, doi: 10.1016/j.seppur.2013.07.046

3. Lorenzi H, Matos FJA. Plantas medicinais no Brasil: nativas e exóticas. 2.ed. Nova Odessa: Instituto Plantarum, 2008, $544 \mathrm{p}$.

4. Marinho JBM, Arruda AMV, Fernandes RTV, Melo AS, Souza RF, Santos LOG, Figueirêdo LC, Fernandes RTV, Mesquita ACN. Uso da moringa na alimentação animal e humana: Revisão. Publ Med Vet Zootec. 2016 Ago;10(8):619-627.

5. Silva FD. Produção de Mudas de Moringa oleifera Lam. submetidas a Adubação Nitrogenada e Fosfatada em Diferentes Recipientes. [monography]. Pombal (CG): Universidade Federal de Campina Grande, Pombal; 2018. 39 p.

6. Mudgil D, Barak S. Composition, properties and health benefits of indigestible carbohydrate polymers as dietary fiber: A review. Int J Biol Macromol. 2013 Oct;61(1):1-6, doi: 10.1016/j.ijbiomac.2013.06.044

7. Delarmelina WM, Caldeira MVW, Faria JCT, Gonçalves EO, Rocha RLF. Diferentes substratos para a produção de mudas de Sesbania virgata. Floresta Ambient. 2014 Jun;21(2):224-233, doi: 10.4322/floram.2014.027

8. Fuglie LJ. The Miracle Tree: Moringa oleifera: Natural Nutrition for the Tropics. Church World Service, Dakar; 1999, $68 \mathrm{p}$.

9. Sbrt. Cultivo da Moringa oleifera. Instituto Euvaldo Lodi - IEL/BA; 2013, 18 p.

10. Peske ST, Rosenthal MD, Rota GRM. Sementes: fundamentos científicos e tecnológicos. $3^{\text {a }}$. ed. Pelotas: Editora Rua Pelotas; 2012, 573 p.

11.Moura SSS, Soares AM, Ursulino MM, Oliveira, R, Nascimento LC, Alves EU. Physiological and sanitary quality of seeds of Dimorphandra gardneriana Tul. treated with essential oils. Comunicata Sci. 2018 May;9(3):457-464, doi: 10.14295/cs.v9i3.1600

12. Flávio NSDS, Sales NLP, Aquino CF, Soares EPS, Aquino LFS, Catão HCRM. Qualidade sanitária e fisiológica de sementes de sorgo tratadas com extratos aquosos e óleos essenciais. Semina: Ciênc Agrár. $2014 \mathrm{Jan} / \mathrm{Fev} ; 35(1): 7-20$, doi: 10.5433/1679-0359.2014v35n1p7

13.Vasconcelos MC. Análise de imagem e sanidade em sementes de Moringa oleifera. [dissertation]. Universidade Federal de Sergipe, Aracaju; 2013. 65 p. 
14. Farias OR, Nascimento LC, Oliveira FS, Santos MDR, Bruno RLA. Óleo essencial de andiroba (Carapa guianensis Aubl.) e copaíba (Copaifera langsdorffi Desf.) sobre a sanidade e fisiologia de sementes de feijão macassar (Vigna unguiculata L. Walp.). Rev Bras Plantas Med. 2016 Mar;18(3):629-635, doi: 10.1590/1983-084X/0112

15. Walker AS, Auclair C, Gredt M, Leroux P. First occurrence of resistance to strobilurin fungicides in Microdochium nivale and Microdochium majus from French naturally infected wheat grains. Pest Manag Sci. 2009 Ago;65(8):906-915, doi: 10.1002/ps.1772

16. Fonseca MCM, Lehner MDS, Gonçalves MG, Júnior P, Silva AF, Bonfim FPG, Prado AL. Potencial de óleos essenciais de plantas medicinais no controle de fitopatógenos. Rev Bras Plantas Med. 2015 Jan/mar;17(1):45-50, doi: 10.1590/1983-084X/12_170

17. Silva RT, Lopez MFQ, Barbosa Neto MA, Farias OR, Nascimento LC, Bruno RLA. Seeds of Calotropis procera treated with essential oils of Copaifera langsdorffii Desf. and Syzygium aromaticum L. J Agric Sci. 2018 Oct;11(4):438-447, doi: 10.5539/jas.v11n1p438

18.Brasil. Ministério da Agricultura, Pecuária e Abastecimento. Regras para análise de sementes/Ministério da Agricultura, Pecuária e Abastecimento. Secretaria de Defesa Agropecuária. 2009. 399 p.

19. Seifert KA, Gams W. The genera of Hyphomycetes - 2011 update. Mol Phyl Evol Fungi. 2011 Dec;27(1):119-129, doi: 10.3767/003158511X617435

20. Maguire JD. Speed of germination-aid in selection and evaluation for seedling emergence and vigor. Crop Sci. 1962 Mar;2(1):176-177, doi: 10.2135/cropsci1962.0011183X000200020033x

21. Nakagawa J. Testes de vigor baseados na avaliação das plântulas. In: Vieira RD, Carvalho NM. Testes de vigor em sementes. Jaboticabal: FUNEP; 1999. p. 49-85.

22. Sousa MV, Machado JC, Kawasaki VH, Araújo DV, Silva AA, Martini Neto A. Methods of inoculation and effects of Fusarium oxysporum f. sp. vasinfectum in cotton seeds. Trop Plant Pathol. 2008 Feb;33(1):41-48, doi: 10.1590/S1982-56762008000100007

23. Ferreira DF. Análises estatísticas por meio do Sisvar para Windows versão 4.0. In: $45^{\text {a }}$ Reunião Anual da Região Brasileira da Sociedade internacional de Biometria. UFSCar, São Carlos, SP. 2012. p. 255 258.

24.Brasil. Ministério da Agricultura, Pecuária e Abastecimento. Instrução Normativa n 45 de 17 de setembro de 2013. Dispõe sobre os padrões para a produção e a comercialização de sementes. Diário Oficial da União, 2013. 16 p.

25.Walker C, Maciel CG, Milanesi PM, Muniz MFB, Mezzomo, R, Pollet CS. Caracterização morfológica, molecular e patogenicidade de Fusarium acuminatum e Fusarium verticillioides a Cordia americana. Ciênc Florestal. 2016 Abr;26(2):463-473, doi: /10.5902/1980509822747

26. Kobayasti L, Pires AP. Levantamento de fungos em sementes de trigo. Pesq Agropecu Trop. 2011 Dez;41(4):572-578, doi: org/10.5216/pat.v41i4.12388

27. Ismaiel AA, Papenbrock J. Mycotoxins: Producing fungi and mechanisms of phytotoxicity. Agriculture. 2015 May;5(3):492-537, doi: 10.3390/agriculture5030492

28. Woudenberg JHC, Seidl MF, Groenewald JZ, De Vries M, Stielow JB, Thomma BPHJ, Crous PW. Alternaria section Alternaria: Species, formae speciales or pathotypes? Studies Mycol. 2015 Sep;82:121. doi: 10.1016/j.simyco.2015.07.001

29. Silva DD, Crous, PW, Ades PK, Hyde KD, Taylor PWJ. Life styles of Colletotrichum species and implications for plant biosecurity. Fungal Biol Rev. 2017 Jun;31(3):55-168, doi: 10.1016/j.fbr.2017.05.001

30. Silva MSBS, Rodrigues AAC, Oliveira LJMG, Silva EKC, Pereira TS. Sanidade de sementes de arroz, biocontrole, caracterização e transmissão de Curvularia lunata em semente-plântula de arroz. Rev Ceres. 2014 Ago;61(4):511-517, doi: 10.1590/0034-737X201461040009

31. Soares ID, Auer CG, Santos ÁF, Tambarussi EV, Rezende EH, Valle Coelho TA, Duin I.M. Fungos associados à mancha foliar em Eucalyptus benthamii Maiden et Cambage na região Sul do Brasil. Biofix Scient J. 2017 Set;2(2):32-37, doi: 10.5380/biofix.v2i2.54469

32. Botelho LS, Moraes MHD, Menten JOM. Fungos associados às sementes de ipê-amarelo (Tabebuia serratifolia) e ipê-roxo (Tabebuia impetiginosa): incidência, efeitos na germinação e transmissão para as plântulas. Summa Phytopathol. 2008 Dez;34(4):343-348, doi:10.1590/S0100-54052008000400008

33. Zhou1 W, Starr JL, Krumm JL, Gregory A, Sword GA. The fungal endophyte Chaetomium globosum negatively affects both above- and belowground herbivores in cotton. Microbiol Ecol. 2016 Jul;92(10):1-15, doi: 10.1093/femsec/fiw158

34. Costa ART, Amaral MFZJ, Martins PM, Paula JAM, Fiuza TS, Resvenzol LMF, Paula JR, Bara MTF. Ação do óleo essencial de Syzygium aromaticum (L.) Merr. \& L.M. Perry sobre as hifas de alguns 
fungos fitopatogênicos. Rev Bras Plantas Med. 2011 13(2):240-245. doi: org/10.1590/S151605722011000200018

35. Silva TB, Rangel ET. Avaliação da atividade antimicrobiana do extrato etanólico do tomilho (Thymus vulgaris 1.) in vitro. Rev Eletr Farm. 2010 Set;7(2):48-58 doi: 10.5216/ref.v7i2.11859

36. Kim JM, Marshall MR, Cornell JA, Preston JF, Wei CI. Antibacterial activity of carvacrol, citral, and geraniol against Salmonella typhimurium in culture medium and on fish cubes. J Food Sci. 1995 Nov;60(6):1364-1368, doi: 10.1111/j.1365-2621.1995.tb04592.x.

37. Xavier MVA, Oliveira CRF, Brito SSS, Matos CHC, Pinto MADSC. Viabilidade de sementes de feijão caupi após o tratamento com óleo essencial de citronela (Cymbopogon winterianus Jowitt). Rev Bras Plantas Med. 2012 Mar;14(2):250-254, doi: 10.1590/S1516-05722012000500021

38. Jardinetti VA, Cruz MES, Maia AJ, Oliveira JSB, Santos EM. Efeito de óleos essenciais no controle de patógenos e na germinação de sementes de milho (Zea mays). In: VII Encontro Internacional de Produção Cientifica, Maringá. 2011. p. 2236-7934

39. Reigosa MJ, Sánchez-Moreiras A, González L. Ecophysiological approach in allelopathy. Critical Rev Plant Sci. 1999 Jun;18(5):577-608, doi: 10.1080/07352689991309405

40. Alves MCS, Medeiros Filho SM, Innecco R, Torres SB. Alelopatia de extratos voláteis na germinação de sementes e no comprimento da raiz de alface. Pesq Agropecu Bras. 2004 Nov;39(11):1083-1086, doi: 10.1590/S0100-204X2004001100005

41. Fantazzini TB, Guimarães RM, Clemente ACS, Carvalho ER, Machado JC. Fusarium verticillioides inoculum potential and its relation with the physiological stored corn seeds quality. Biosci J. 2016 Oct;32(5):1254-1262, doi.org/10.14393/BJ-v32n5a2016-33056

42. Silva TWR, Santos ÁF, Auer CG, Tessmann DJ. Métodos de detecção, transmissão e patogenicidade de Fusarium spp. em sementes de Pinus taeda. Ciênc Florestal. 2017 Mar;27(1):73-84, doi: $10.5902 / 1980509826448$

43. Maciel C, Muniz M, Santos AF, Lazarotto M. Detecção, transmissão e patogenicidade de fungos em sementes de angico-vermelho (Parapipta deniarigida). Summa Phytopathol. 2012 Mai;38(4):323-328, doi: 10.1590/S0100-54052012000400009

44. Lazarotto M, Muniz MFB, Beltrame, R, Santos ÁF, Maciel CG, Longhi SJ. Sanidade, transmissão via semente e patogenicidade de fungos em sementes de Cedrela fissilis procedentes da região sul do Brasil. Ciênc Florestal. 2012 Set;22(3):493-503, doi: 10.5902/198050986617 